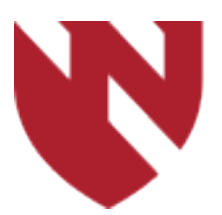

September 2020

\title{
Right Ventricular Lead Dysfunction Post LVAD Implantation
}

\author{
Ahmed Mohamed Abdelhalim-Selim \\ University of Nebraska Medical Center \\ Rahul Dhawan \\ University of Nebraska Medical Center \\ Katherine Germann \\ University of Nebraska Medical Center \\ Scott Lundgren \\ University of Nebraska Medical Center \\ Ronald Zolty \\ University of Nebraska Medical Center
}

See next page for additional authors

Tell us how you used this information in this short survey.

Follow this and additional works at: https://digitalcommons.unmc.edu/gmerj

Part of the Higher Education Commons, and the Medicine and Health Sciences Commons

\section{Recommended Citation}

Abdelhalim-Selim, A. M., Dhawan, R., Germann, K., Lundgren, S., Zolty, R., , Khan, F. Right Ventricular Lead Dysfunction Post LVAD Implantation. Graduate Medical Education Research Journal. 2020 Sep 29; 2(1). https://digitalcommons.unmc.edu/gmerj/vol2/iss1/80

This Conference Proceeding is brought to you for free and open access by DigitalCommons@UNMC. It has been accepted for inclusion in Graduate Medical Education Research Journal by an authorized editor of DigitalCommons@UNMC.For more information, please contact digitalcommons@unmc.edu. 


\section{Right Ventricular Lead Dysfunction Post LVAD Implantation}

Creative Commons License

(c) (i) (9)

This work is licensed under a Creative Commons Attribution-Noncommercial-No Derivative Works 4.0 License.

\section{Authors}

Ahmed Mohamed Abdelhalim-Selim, Rahul Dhawan, Katherine Germann, Scott Lundgren, Ronald Zolty, and Faris Khan 
Conclusion: CPM and QM set by ACC/AHA are not always met during care of post-AMI patients. One common barrier is documenting contraindications to recommended therapies. Quality improvement projects should be implemented to optimize the rate of CPM and QM met.

https://doi.org/10.32873/unmc.dc.gmerj.2.1.058

\section{Right Ventricular Lead Dysfunction Post LVAD Implantation}

Ahmed Mohamed Abdelhalim-Selim¹, Rahul Dhawan', Katheine Germann¹, Scott Lundgren'1, Ronald Zolty ${ }^{1}$, Faris Khan ${ }^{1}$

${ }^{1}$ University of Nebraska Medical Center, Department of Internal Medicine, Division of Cardiovascular Disease

\section{Mentor: Faris Khan}

Program: Internal Medicine, Division of Cardiovascular Disease

Type: Original Research

Background: The use of left ventricular assist devices (LVAD), both as bridge to cardiac transplantation as well as destination therapy, has increased significantly over the last few years. The vast majority of these patients are eligible for electrical implantable devices (including single, dual chamber, and biventricular defibrillators). There is scarcity of data on the impact of LVAD placement on the right ventricular lead integrity in these devices

Methods: We studied a total of 50 patients who had implantable cardioverter device (single, dual chamber and biventricular device) prior to LVAD placement at the University of Nebraska between 2017 and 2019, a chart review was done to identify patients with right ventricular lead dysfunction that was diagnosed post LVAD implantation.

Results: The mean age of patients at the time of LVAD was $54(+/-14)$ years, the study included 41 males $(82 \%)$. Forty-two patients had Heartmate III, four had Heartmate II and four patients had Heartware LVAD.
Twenty seven patients had single or dual chamber ICD (54\%) while 23 patients had a biventricular ICD (46\%). Right ventricular lead malfunction was reported in 18 patients (36\%) within 6 months of LVAD implantation. The type of left ventricular assist devices and electrical devices were not significantly

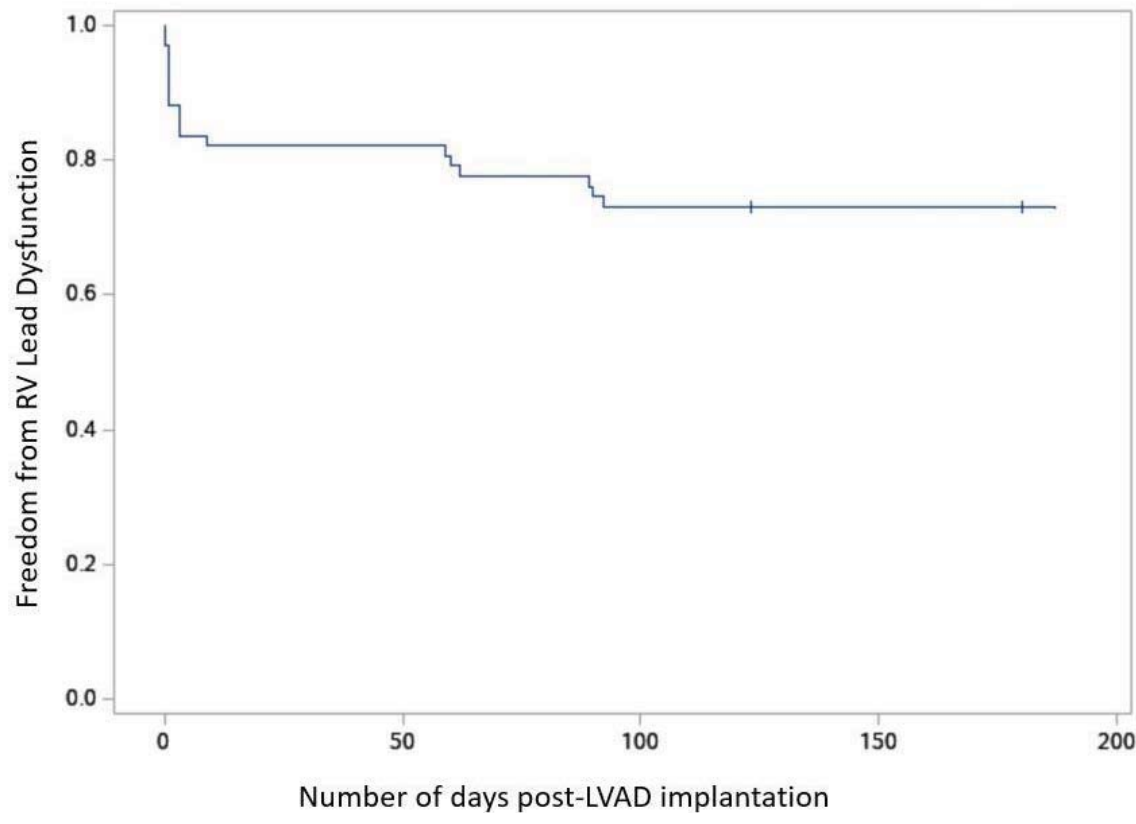

Figure 1. ICD* lead malfunction in first 6 months after LVAD* implant. *ICD: Implantable Cardioverter Defibrillator; LVAD: Left Ventricular Assist Device. different in the RV lead malfunction group compared to the rest of the patients.

Conclusion: There is a high incidence of right ventricular lead dysfunction post implantation of left ventricular assist devices.

https://doi.org/10.32873/unmc.dc.gmerj.2.1.078

\section{Are We Missing Vitamin Deficiencies in Parkinson's Disease?}

Praveen Hariharan ${ }^{1}$, Erin L. Smith², Nabeel M. Syed ${ }^{2}$, Bobbi J. Roeder ${ }^{2}$, Jenna Paseka ${ }^{1}$, Danish Bhatti ${ }^{2}$, Diego R. Torres-Russotto ${ }^{2}$, John M. Bertoni ${ }^{2}$ ${ }^{1}$ University of Nebraska Medical Center, Department of Neurological Sciences

${ }^{2}$ University of Nebraska Medical Center, Department of Neurological Sciences, Division of Movement Disorders

Mentor: John M. Bertoni

Program: Neurological Sciences, Division of Movement Disorders

Type: Case Report

Background: Parkinson's disease (PD) management focuses on quality of life, including adequate nutrition. Extensive literature has correlated nutritional deficiencies and PD, but they are still commonly missed. Many new neurological symptoms are attributed to disease progression without ruling out these treatable conditions.

Methods: We present three cases of PD patients with diverse neurological symptoms whose workup showed reversible vitamin deficiencies.
Results: Case 1 This 81-year-old male physician with PD developed weight loss, irritability, and dementia attributed to advanced disease. Workup revealed low thiamine (B1) of $30 \mathrm{nmol} / \mathrm{L}$ (70-180), pyridoxine (B6) of $5.2 \mathrm{nmol} / \mathrm{L}$ (20.0-125.0), cobalamin (B12) of $72 \mathrm{pg} / \mathrm{mL}(180-914)$, and 25-hydroxyvitamin D of $14 \mathrm{ng} / \mathrm{mL}$ (30-80). He was noncompliant with replacement and passed away. Case 2 This 90-year-old woman 